\title{
Peran Orang Tua dalam Pemanfaatan Teknologi Digital pada Anak Usia Dini
}

\author{
Luluk Asmawati ${ }^{\bowtie}$ \\ Pendidikan Anak Usia Dini, Universitas Sultan Ageng Tirtayasa \\ DOI: $10.31004 /$ obsesi.v6i1.1170
}

\begin{abstract}
Abstrak
Pandemic COVID-19 menghadirkan tantangan bagi pelaksanaan pembelajaran PAUD sehingga orang tua berperan penting dalam pemanfaatan teknologi digital. Penelitian ini bertujuan untuk mengetahui pengaruh pemanfaatan teknologi digital terhadap peran orang tua pada anak usia dini. Penelitian ini merupakan penelitian kuantitatif dengan metode survei. Jumlah sampel sebanyak 277 responden (Orang tua). Penelitian ini dilaksanakan di Provinsi Banten, Indonesia. Angket digunakan untuk mengumpulkan data penelitian yang disusun berdasarkan skala Likert. Angket divalidasi oleh tiga ahli dengan tiga cara, yakni validitas isi, konstruk, dan empiris. Analisis data pada penelitian ini menggunakan SEM (Structural Equation Model) dengan software SmartPLS versi 3.0. Hasil penelitian menunjukkan bahwa terdapat pengaruh positif dan signifikan teknologi digital terhadap peran orang tua dalam memanfaatkan gadget. Hasil penelitian ini dapat dijadikan petunjuk bagi orang tua dalam memanfaatkan teknologi sehingga orang tua dapat memaksimalkan perannya dengan segala perkembangan yang terjadi.
\end{abstract}

Kata Kunci: pemanfaatan; teknologi digital; pandemi covid-19, paud.

\begin{abstract}
The COVID-19 pandemic presents a challenge for the implementation of PAUD learning so that parents play an important role in the use of digital technology. This study aims to determine the effect of the use of digital technology on the role of parents in early childhood. This research is a quantitative research with a survey method. The number of samples was 277 respondents (parents). This research was conducted in Banten Province, Indonesia. Questionnaires are used to collect research data arranged on a Likert scale. The questionnaire was validated by three experts in three ways, namely content, construct, and empirical validity. Data analysis in this study used SEM (Structural Equation Model) with SmartPLS version 3.0 software. The results showed that there was a positive and significant effect of digital technology on the role of parents in utilizing gadgets. The results of this study can be used as a guide for parents in utilizing technology so that parents can maximize their role with all the developments that occur.
\end{abstract}

Keywords: utilization; digital technology; the covid-19 pandemic; early childhood education programs

Copyright (c) 2021 Luluk Asmawati

$\triangle$ Corresponding author :

Email Address : lulukasmawati@untirta.ac.id (Jakarta, Indonesia)

Received 28 February 2021, Accepted 14 March 2021, Published 21 march 2021 


\section{PENDAHULUAN}

Kondisi pandemic covid-19 mengharuskan seluruh elemen pendidikan untuk mengalihkan pembelajaran dengan memanfaatkan teknologi, tidak terkecuali pendidikan anak usia dini (Chusna \& Utami, 2020). Kurikulum PAUD juga disederhana selama masa pandemic agar guru memiliki panduan prioritas selama mengajar. Beberapa saluran komunikasi juga difasilitasi oleh Kementerian Pendidikan dan Kebudayaan untuk para pendidik agar pembelajaran tetap dapat berjalan seperti sebelumnya. Dengan adanya kebijakan tersebut, tentunya menjadi aturan tidak tertulis mengenai keterampilan pendidik dalam pengimplementasian pembelajaran berbasis teknologi, seperti penggunaan android, personal computer, maupun IPad. Lembaga pendidikan harus menyusun langkah inovatif sebagai bentuk tindak lanjut pelaksanaan pembelajaran daring.

Pembelajaran daring di masa pandemic mengharuskan dua pihak (pendidik dan orang tua) untuk bekerja sama. Orang tua juga memiliki peran khusus dalam pelaksanaan kebijakan ini. Pada era digital, keluarga harus tetap mempertahankan dimensi fisik, tatap muka, dan menjalin proses komunikasi yang harmonis (Ebi, 2017). Orang tua memiliki peran sebagai pendidik pertama dan utama yang memiliki tanggung jawab untuk membentuk dan membina anak-anak secara fisik dan psikologis. Ada beberapa peran orang tua dalam mendidik anak di era digital, antara lain: (1) membatasi anak menggunakan gadget dan media digital lainnya, (2) mendorong anak melakukan aktivitas motorik lainnya, (3) memilihkan media atau tayangan yang tepat dan aman bagi anak, (4) memonitoring lingkungan dunia maya anak, (5) mendampingi dan memantau aktivitas anak dalam mengakses dan menggunakan media sosial, (6) menunjukkan teladan yang baik dan positif menggunakan media sosial, serta (7) advisor, asesor, konselor, demonstrator, sahabat, fasilitator, pencari fakta, sumber pengetahuan, mentor, motivator, role model, supporter bagi anak usia dini untuk menggunakan media social (Santosa, 2015).

Berdasarkan hasil studi pendahuluan melalui penyebaran angket yang dilakukan oleh Aisyatinnaba \& Sutoyo (2016) di SMP Negeri 3 Lorasi Kabupaten Brebes menunjukkan fenomena bahwa orang tua sibuk dengan pekerjaannya sehingga mereka kurang memperhatikan perannya untuk mendidik anak. Lebih lanjut, mereka menjelaskan bahwa orang tua kurang memahami perannya dan menganggap bahwa guru di sekolahnya memegang penuh tugas pendidikan anaknya. Luciana (2015) mengemukakan beberapa orang tua menganggap kewajiban orang tua untuk mendidik anak lepas setelah mereka menyerahkan anak ke sekolah. Menurut Luciana, anggapan seperti itu merupakan hal yang kurang tepat karena orang tua seharusnya mengetahui fungsi dan tugas tutor di sekolah.

Studi pendahuluan lain yang dilakukan oleh Irma et al. (2019) di TK Mayithoh 1 Purworejo melalui hasil wawancara dan angket terungkap bahwa jika rendahnya peran orang tua untuk mendidik anaknya disebabkan oleh sebagian orang tua yang sibuk bekerja. Akibatnya, orang tua tidak sempat mengecek ataupun mengulas materi pelajaran anaknya, serta lemahnya pengetahuan orang tua mengenai materi yang telah diajarkan guru kepada siswa. Ulasan yang hampir serupa juga dikemukakan oleh Elihami dan Ekawati (2020), sebagian orang tua di Desa Tokkonan, Kecamatan Enrekang, Kabupaten Enrekang menganggap pendidikan PAUD tidak telalu penting untuk diikuti karena aktivitas yang dilakukan anak hanya bermain, bernyanyi, dan bertepuk tangan. Bagi orang tua di Desa Tokkonan, hal yang lebih penting yaitu memasukkan anak secara langsung di sekolah dasar. Menurut pendapat Ahsani (2020), proses pembelajaran di rumah dengan kondisi sekarang, guru lebih banyak memberikan tugas kepada siswa tanpa didahului pemberian materi lebih dahulu. Orang tua merasa keberatan dengan kondisi tersebut karena kesehatan mental dan psikis anak menjadi turun dengan adanya tuntutan belajar selama 24 jam.

Dengan mempertimbangkan masalah tersebut, maka perlu adanya solusi yang relevan dengan kondisi pandemic saat ini. Teknologi menjadi bagian yang tidak terpisahkan dalam pembelajaran selama masa COVID-19. Kemajuan teknologi berkembang semakin pesat dengan kemudahan yang diberikan untuk mengakses informasi. Kemajuan teknologi 
menciptakan kegiatan semakin cepat dan tak terbatas. Penggunaan teknologi dapat menjadi sumber belajar bagi peserta didik. Kemajuan ini harus disikapi dengan bijak dan tepat guna agar memberikan kebermanfaatan bagi seluruh penggunanya.

Perkembangan teknologi tidak hanya terfokus pada teknologi pervasive saja, akan tetapi telah memiliki keragaman berupa perangkat bergerak atau gadget. Sekarang, interaksi manusia dengan televisi semakin tertinggal dibandingkan interaksi dengan handphone. Alasannya yaitu handphone mudah dan ringan dibawa dan multi fungsi yaitu dapat dimanfaatkan untuk menonton televisi, memutar audio, dan merekam video (Ulfa, 2016). Dapat dikatakan bahwa seseorang tanpa sadar telah diperkenalkan teknologi oleh lingkungan sekitarnya. Dengan demikian, media handphone dapat dimanfaatkan untuk membelajarkan anak oleh orang tua. Pembelajaran tersebut dapat berupa pengenalan literasi dan berhitung.

Gadget memiliki bermacam fitur game. Fitur game pada gadget tidak hanya sebagai hiburan atau game saja, tetapi juga untuk membantu proses belajar anak dan sebagai media pembelajaran (Warisyah, 2015), seperti fitur game edukasi. Menurut Ismail Haryanto \& Friana (2018), game edukasi merupakan alat pendidikan bagi guru untuk mendidik dan mengajar dengan menyenangkan. Aplikasi game edukasi berhasil mengubah teknik belajar formal yang monoton menjadi menyenangkan dan lebih edukatif bagi anak usia dini, seperti anak dapat mengenal dan memahami huruf dan angka (Fithri \& Setiawan, 2017). Hasil penelitian Irsa et al. (2015) menyimpulkan bahwa game edukasi bagi anak usia dini terbukti dapat meningkatkan minat belajar anak dengan hasil respon mencapai 78,33\% dinyatakan sangat bagus.

Pemanfaatan media teknologi dalam pembelajaran daring oleh guru PAUD diantaranya whatsapp, google meet, zoom, video call, media social, siaran televisi, dan buku tema sekolah (Fujiawati et al., 2020). Dari sekian banyak aplikasi, whatsapp menjadi platform yang sering digunakan dan cukup membantu pelaksanaan pembelajaran anak di rumah. Studi terdahulu memberikan kesimpulan bahwa pemanfaatan teknologi dalam pembelajaran PAUD memberikan rangsangan dan membangkitkan semangat peserta didik (Hardiyana, 2016).

Secara umum, menurut Sahriana (2019), penggunaan gadget memberikan dampak positif sebagai berikut: (1) menambah pengetahuan, (2) memperluas jaringan persahabatan, (3) mempermudah komunikasi, dan (4) melatih kreativitas anak. Selain itu, penggunaan gadget juga memberikan dampak negative, diantaranya: (1) mengganggu kesehatan, (2) mengganggu perkembangan anak, (3) rawan terhadap tindak kejahatan, dan (4) mempengaruhi perilaku anak. Dengan mempertimbangkan dampak negative dari gadget, maka peran orang tua sangatlah penting. Ada beberapa cara yang dapat dilakukan orang tua, antara lain: (1) memilihkan fitur pada gadget yang sesuai dengan usia anak; (2) mendampingi anak selama penggunaan gadget; (3) memberi batasan waktu anak untuk menggunakan gadget; (4) menghindari kecanduan gadget pada anak dengan memberikan aturan; dan (5) membantu anak menyesuaikan diri dengan lingkungan dan perkembangan zaman (Ferliana, 2013).

Keterlibatan orang tua dalam pengontrolan penggunaan gadget anak juga sangat dibutuhkan, baik dalam bentuk motivasi, kasih sayang, maupun tanggung jawab (Warisyah, 2015). Para orang tua harus lebih berhati-hati terhadap resiko yang diakibatkan dari pemakaian gadget yang berlebihan. Dari hasil penelitian, penggunaan media pembelajaran melalui aplikasi terbukti berhasil meningkatkan kemampuan anak sehingga tenaga pendidik perlu memahami bentuk teknologi pembelajaran, prosedur pengoperasiannya, dan cara menginteraksikan teknologi dengan peserta didik selama proses pembelajaran (Barovih et al., 2020).

Penelitian serupa telah dilakukan oleh beberapa peneliti sebelumnya. Novianti dan Garzia (2020) telah melaksanaan penelitian dengan judul "Penggunaan Gadget pada Anak Usia Dini; Tantangan Baru Orang Tua Milenial". Dalam penelitian, mereka menyimpulkan 
bahwa penggunaan gadget pada usia 2-7 tahun masih membutuhkan aturan dan pendampingan orang tua agar dampak negative dari gadget tetap terhindar. Persamaan penelitian ini dengan penelitian Novianti dan Garzia yaitu sama-sama untuk mengetahui peran orang tua dalam penggunaan gadget kepada anak. Namun, penelitian terdahulu oleh Novianti dan Garzia memiliki perbedaan dengan penelitian ini. Perbedaannya yaitu tempat pelaksanaan penelitian dimana penelitian ini dilaksanakan di Provinsi Banten, sedangkan penelitian sebelumnya dilaksanakan di Pekanbaru. Wilayah penelitian tentu mempengaruhi kondisi perkembangan peserta didik. Pengaruhnya dapat dilihat dari fasilitas yang didapatkan maupun proses pembelajaran anak PAUD. Selain itu, focus penelitiannya mengulas mengenai keluhan anak setelah menggunakan gadget, sedangkan penelitian ini menyajikan hasil survey kegiatan teknologi digital yang dilakukan anak sebagai upaya pemanfaatan gadget.

Studi penelitian serupa juga dilakukan Iftitah dan Anawaty (2020) dengan judul "Peran Orang Tua dalam Mendampingi Anak di Rumah selama Pandemi COVID-19". Penelitiannya dengan penelitian ini sama-sama membahas mengenai peran orang tua terhadap anak usia dini. Perbedaan penelitian ini dengan penelitian sebelumnya yaitu: (1) penelitian ini menggunakan metode survey, sedangkan penelitian sebelumnya menggunakan metode studi pustaka; (2) penelitian ini menggunakan angket sebagai alat pengumpul data, sedangkan penelitian sebelumnya menggunakan dokumentasi berupa buku dan jurnal; dan (3) dalam penyajian data, penelitian ini menggunakan tabel untuk menampilkan hasil penelitian, sedangkan penelitian sebelumnya hanya berupa narasi dari analisis beberapa buku maupun jurnal.

Penelitian yang berjudul "Analisis Peran Orang Tua dalam Mendampingi Anak di Masa Pandemi Covid-19" mengulas secara mendalam melalui studi kasus (Kurniati et al., 2021). Namun, jumlah sampel penelitian yang dilakukan oleh Kurniati et al. hanya 9 orang saja, sedangkan penelitian ini menggunakan jumlah sampel 277 orang tua. Perbedaan lain pun mencolok pada hal-hal yang dianalisis. Penelitian sebelumnya memaparkan peran orang tua selama pandemi, yaitu: (1) menjaga dan memastikan anak untuk hidup bersih dan sehat, (2) mendampingi anak dalam mengerjakan tugas sekolah, (3) melakukan kegiatan bersama selama di rumah, (4) menciptakan lingkungan yang nyaman untuk anak, (5) menjalin komunikasi dengan anak, (6) bermain dengan anak, (7) menjadi role model bagi anak, (8) memberikan pengawasan, (9) memenuhi kebutuhan, (10) membimbing dan memberi motivasi, (11) mengedukasi, (12) memelihara nilai keagamaan, dan (13) melakukan inovasi kegiatan di rumah. Sementara itu, penelitian ini akan membahas dua hal penting mengenai pemanfaatan gadget bagi anak dan peran orang tua terhadap pemanfaatan gadget. Dua hal ini memaparkan hal yang berbeda dan disajikan pula persentase jawaban dari setiap aspek yang diukur.

Studi penelitian lain dengan judul "Pendampingan Orang Tua pada Anak Usia Dini dalam Penggunaan Teknologi Digital" memaparkan secara naratif tentang peran teknologi komunikasi, determinasi teknologi, motif orang tua memberikan teknologi pada anak usia dini, dampak positif dan negatif teknologi bagi anak, peran orang tua di era digital (Alia \& Irwansyah, 2018). Beberapa hal tersebut diulas secara kualitatif, akan tetapi tidak menyebutkan wilayah penelitiannya. Relevansi dari penelitian ini terdapat pada teknologi sebagai alatnya, orang tua sebagai pengguna, dan anak usia dini sebagai penerima pendamping. Perbedaan penelitian ini dengan penelitian sebelumnya yaitu dilihat dari pendekatan penelitian yang digunakan, tujuan penelitian, dan aspek yang dinilai. Dalam penelitian ini, peneliti menggunakan metode survey, dengan tujuan penelitian mengidentifikasi peran orang tua dalam pemanfaatan teknologi bagi anak usia dini, dan aspek-aspek seperti halnya pemanfaatan gadget sebagai teknologi yang ditekankan dan peran serta orang tua dalam membantu anak untuk memanfaatkan gadget.

Dengan melihat hasil analisis beberapa artikel yang hampir serupa dengan penelitian ini, maka masih layak dikatakan bahwa penelitian ini masih memiliki kebaruan 
penelitian tersendiri. Beberapa bukti kuat bahwa penelitian ini orisinil yaitu dari empat artikel yang dianalisis, belum ada peneliti terdahulu yang menggunakan sampel diwilayah yang sama dengan penelitian ini. Selain itu, penelitian ini difokuskan pada pemanfaatan gadget sebagai edukasi untuk permainan, mengaji, mewarnai, menggambar, dan berhitung, sedangkan peran orang tua hanya difokuskan pada pendampingan sesuai platform yang sesuai karakter anak PAUD. Penelitian ini berusaha untuk mengungkap penggunaan gadget yang sesuai dengan usia PAUD. Penyajian data juga cukup berbeda dengan artikel yang telah dianalisis, dimana penelitian terdahulu lebih banyak menyajikan dalam bentuk narasi saja. Berpijak dari urgensi hingga kebaruan penelitian, maka tujuan penelitian ini yaitu mengidentifikasi peran orang tua dalam pemanfaatan teknologi terhadap anak usia dini.

\section{METODOLOGI}

Penelitian ini menggunakan penelitian kuantitatif. Metode yang digunakan yaitu metode survey. Metode ini bertujuan untuk menggambarkan secara kuantitatif kecenderungan tindakan dari populasi dengan cara meneliti seluruh sampel populasinya (Creswell \& Creswell, 2017). Perilaku yang dimaksud dalam penelitian ini yaitu pemanfaatan teknologi digital anak usia dini terhadap peran orang tua selama masa pandemic COVID-19. Metode ini dipilih karena peneliti ingin mengidentifikasi respon orang tua melalui angket terhadap pemanfaatan teknologi serta peran apa saja yang dilakukan oleh orang tua dalam memanfaatkan teknologi tersebut. Dengan begitu, metode survey dirasa sangatlah cocok untuk digunakan dan sejalan dengan fungsi dari penelitian survey yakni untuk mengumpulkan dan menjelaskan opini atau pendapat dari sekelompok orang (sampel penelitian) terhadap topic tertentu.

Jumlah sampel penelitian ini yaitu 277 responden (orang tua). Teknik pengambilan sampel penelitian ini dilakukan secara acak (random sampling). Lokasi penelitian di Provinsi Banten, Indonesia. Data penelitian ini didapatkan secara online melalui platform google form. Instrument yang digunakan yaitu angket mengenai pemanfaatan teknologi melalui peran orang tua. Instrument angket umumnya digunakan sebagai instrument berbasis survey atau riset untuk mengetahui respon mengenai keadaan nyata yang dialami responden. Pernyataan dalam angket penelitian ini sejumlah 20 pernyataan. Ada lima skala likert yang digunakan yakni sangat sering (5), sering (4), kadang-kadang (3), pernah (2), dan tidak pernah (1). Teknik validitas data penelitian menggunakan validitas isi, konstruk, dan empiric. Validitas isi dilakukan dengan menguji kelayakan atau relevansi isi angket melalui analisis rasional oleh ahli yang berkompeten. Adapun validatornya yaitu validator pertama Prof. Dr. H. Sholeh Hidayat, M.Pd. (Dosen Universitas Sultan Ageng Tirtayasa), validator kedua Dr. Uwes Anis Chaeruman (Dosen Universitas Negeri Jakarta), dan validator ketiga Astuti Ambarwati, M.Pd. (Kepala TK Aisyiyah 3 Kota Serang). Berdasarkan hasil uji, para panel memberikan komentar bahwa butir angket dinyatakan layak untuk kemudian diujicobakan secara validitas empiric.

Selain validitas isi, penelitian ini juga menggunakan validitas konstruk. Validitas konstruk adalah sebuah gambaran yang menunjukkan sejauhmana alat ukur itu menunjukkan hasil yang sesuai dengan teori (Azwar, 2016). Dalam memvalidasi secara konstruk, panel juga menganalisis kaidah-kaidah penulisan instrument angket agar tidak multitafsir ketika responden menjawab sejumlah pernyataan butir angket. Validitas empiric juga digunakan dalam penelitian. Caranya dengan mengujicobakan sejumlah butir angket pada orang tua yang masih dalam satu populasi penelitian ini, akan tetapi bukan sampel penelitian. Perhitungan uji validitas empiric menggunakan rumus produk moment. Hasil uji coba empiric penelitian ini dengan menghitung konsistensi internalnya menghasilkan bahwa 20 instrumen memiliki indeks konsistensi internal $\geq 0.30$ (dapat digunakan). Sementara itu, perhitungan reliabilitas dilakukan dengan rumus alpha cronbach. Hasil perhitungan reliabilitas mencapai nilai alpha $>0,7$ (mencukupi) sehingga instrument layak digunakan dalam penelitian. Setelah dilakukan perhitungan validitas dan reliabilitas instrument, maka 
dengan hasil yang telah dijelaskan, instrument penelitian benar-benar dapat digunakan sebagai alat pengumpul data penelitian ini.

Metode analisis penelitian ini menggunakan pendekatan Structural Equation Modeling (SEM) berbasis varian yang secara simultan dapat melakukan pengujian model pengukuran sekaligus pengujian model struktural (Hartono \& Abdillah, 2009). Penelitian ini akan menggunakan alat analisis Partial Least Square (PLS) untuk menguji hipotesis penelitian. Adapun alat analisis yang digunakan adalah software SnartPLS versi 3. Analisis data dalam penelitian ini dilakukan secara langsung sesuai data yang ada. Adapun prosedur penelitian ini dijelaskan pada Gambar 1 berikut.

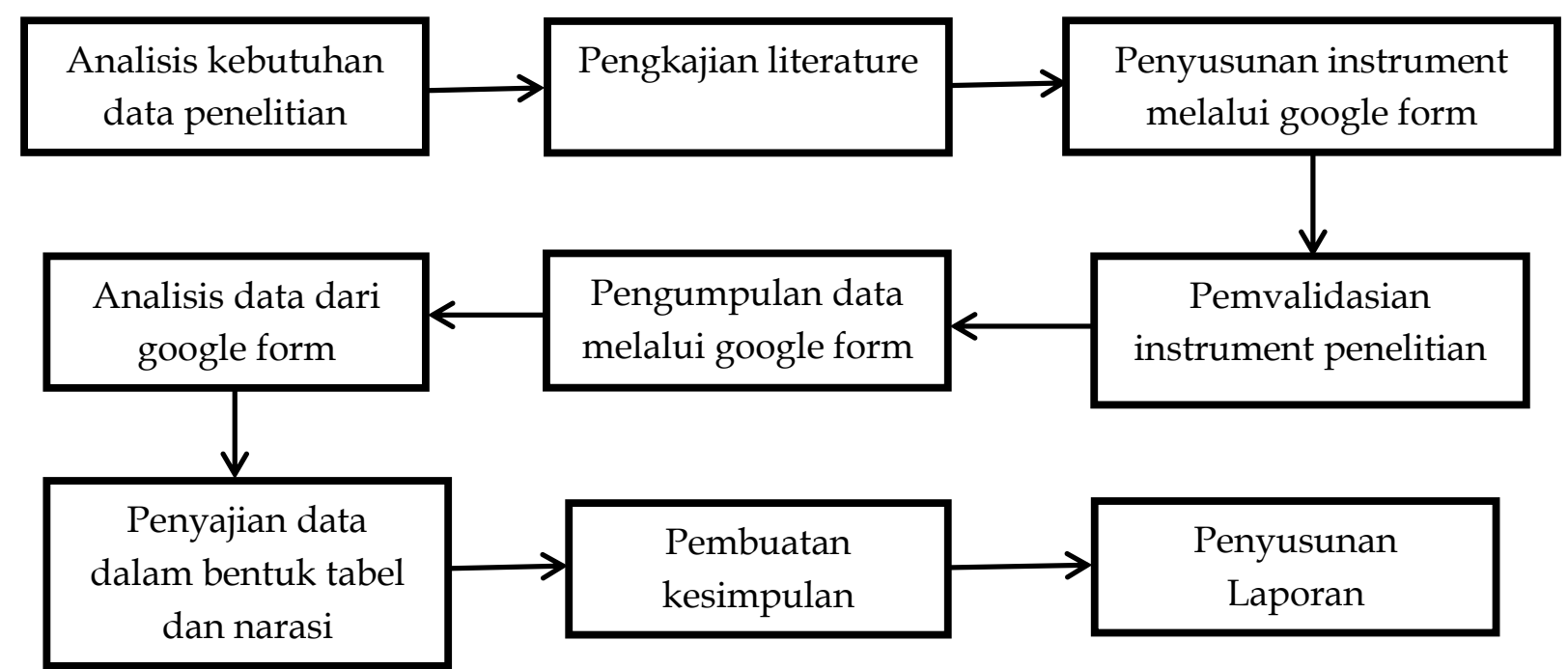

Gambar 1. Prosedur Penelitian

\section{HASIL DAN PEMBAHASAN}

Pemanfaatan teknologi digital di era pandemi seperti ini memudahkan siapa saja untuk mengakses berbagai jenis informasi dengan cepat. Anak-anak di era generasi digital menjadi sangat cepat beradaptasi terhadap perkembangan teknologi informasi. Oleh karena itu, peran orang tua sangat penting dalam menghadapi berbagai tantangan untuk mengasuh dan mengontrol anak-anak. Hasil penelitian yang akan diuraikan mencakup hasil survey pemanfaatan gadget dan penilaian peran orang tua di masa pandemic COVID-19. Hasil survey rata-rata terkait kegiatan anak dalam memanfaatkan teknologi digital tersaji pada Tabel 1.

Tabel 1. Rata-rata Hasil Survey Pemanfaatan Gadget

\begin{tabular}{clc}
\hline No & \multicolumn{1}{c}{ Kegiatan Teknologi Digital Anak } & Skor \\
\hline 1 & Pemanfaatan gadget untuk games edukasi & 2,401 \\
2 & Pemanfaatan gadget untuk mengaji & 4,3 \\
3 & Pemanfaatan gadget untuk mewarnai & 3,968 \\
4 & Pemanfaatan gadget untuk menggambar & 3,964 \\
5 & Pemanfaatan gadget untuk mengenal huruf, angka, membaca, dan berhitung & 4,051 \\
\hline
\end{tabular}

Berdasarkan Tabel 1 dapat dilihat bahwa persentase tertinggi (kegiatan yang sangat sering dilakukan) dalam pemanfaatan gadget anak usia dini terdapat pada kegiatan mengaji. Proses pengajaran mengaji telah menggunakan aplikasi edukatif sebagai sarana pendidikan islami anak usia dini. Pemanfaatan aplikasi mengaji yang dapat orang tua ajarkan pada anak yaitu: asmaul husna, pengenalan huruf hijaiyah, metode iqro, metode BIL Hikmah, metode asosiasi (Metas-Q), dan metode menghafal Al Qur'an. Aplikasi edukatif mengaji bertujuan untuk mendidik, menambah karakter islami dan sekaligus belajar sambil bermain. Hal ini 
didukung oleh Gunawan (2019) bahwa dengan adanya aplikasi edukasi pengenalan huruf hijaiyah di gadget, anak-anak dapat tertarik belajar karena aplikasi tersebut ditunjang dengan adanya suara dan cara pengucapannya. Senada dengan pendapat Nisa et al. (2020) bahwa aplikasi berbasis android menggunakan Unity 3D mampu meningkatkan daya tarik anak-anak untuk belajar huruf Hijaiyyah karena memberikan rasa senang dan tidak membuat jenuh. Selain itu, Hoerunnisa et al. (2019) dalam penelitiannya juga menunjukkan bahwa aplikasi pengenalan huruf hijaiyah berbasis marker augmented reality berada pada kategori sangat baik. Dalam hal ini, orang tua juga berperan untuk menjelaskan cara mengakses aplikasi tersebut dan berkolaborasi dengan anak agar pemanfaatan gadget untuk mengaji lebih maksimal. Hasil survey tersebut sejalan dengan penelitian sebelumnya oleh (Arifin, 2019; Haryanto \& Friana, 2018) bahwa salah satu manfaat dari aplikasi gadget ialah adanya aplikasi pembelajaran mengaji sehingga anak maupun orang tua dapat saling berkolaborasi untuk menambah pengetahuan tentang agama sekaligus sebagai cara belajar anak sambil bermain.

Gadget juga dimanfaatkan oleh anak-anak untuk mengenal huruf, mengenal angka, membaca, dan belajar berhitung. Sebelum anak dapat membaca, menulis, atau menghitung, tentu anak harus dikenalkan dengan huruf dan angka. Dari hasil penelitian ini, orang tua mengajarkan anak tentang konsep huruf dan angka terlebih dahulu hingga anak dapat berpikir kritis dan mandiri. Setelah anak menguasai huruf dan angka, orang tua dapat menggunakan gadget untuk melatih membaca dan berhitung. Kemampuan membaca berkaitan dengan keterampilan berbahasa yang bertujuan untuk menanamkan ide, gagasan, serta perasaan yang ada pada teks (Irhandayaningsih, 2019), sedangkan berhitung berkaitan dengan bilangan yang didalamnya terdapat kegiatan menyebutkan bilangan, mengidentifikasi bilangan, membandingkan, serta mengoperasikan bilangan (Raghubar \& Barnes, 2016). Anak usia 4-5 tahun dapat menyebutkan urutan bilangan sampai sepuluh. Aplikasi berhitung digunakan oleh orang tua untuk mengasah keterampilan berhitung pada anak usia dini sesuai dengan tingkatannya. Hal ini sejalan dengan pendapat Zaini dan Soenarto (2019) bahwa 78\% orang tua menyatakan perlunya aplikasi calistung yang porsinya sesuai dengan kebutuhan anak prasekolah dan bertujuan untuk mengasah perkembangan kompetensi anak. Selaras dengan pendapat Reswita dan Wahyuni (2018) bahwa konsep bilangan adalah salah satu konsep matematika yang penting untuk dikuasai oleh anak dalam setiap pembelajaran matematika. Hasil penelitian Farkhatin (2018) juga menunjukkan bahwa penyampaian materi dalam aplikasi belajar berhitung sangat mudah dipelajari, karena memadukan visual dan audio, sehingga materi mudah dicerna oleh anak dan meningkatkan ketertarikan anak dalam belajar. Dengan belajar membaca dan berhitung, maka anak akan mudah mengikuti pembelajaran di sekolah formal.

Pemanfaatan gadget juga digunakan untuk belajar menggambar maupun mewarnai. Orang tua memiliki tugas untuk mendampingi anak dalam pemanfaatan kegiatan tersebut. Pada sarana menggambar, orang tua mengenalkan kepada anak mengenai aplikasi yang dapat diakses, seperti picks, art kids, learn and draw, drawing for kids and toddlers, dan let's draw with kids. Sementara itu, peran orang tua untuk memaksimalkan pemanfaatan gadget dalam kegiatan mewarnai dilakukan dengan beberapa hal, antara lain: mari mewarnai program unity vutoria, pengenalan warna macromedia flash C6, kids center coloring, live texturing coloring book, mewarnai untuk anak, kids painting colouring book, toodler colouring book free, kids doodlecolour and draw, dan colour kids-disney colouring. Orang tua juga menjelaskan prosedur dari penggunaan aplikasi tersebut. Melalui penjelasan tersebut, anak memiliki inisiatif sendiri dan lebih kritis terhadap hal-hal baru yang mereka hadapi selama mengakses aplikasi.

Hasil survey tersebut masih sejalan dengan penelitian sebelumnya, dimana anakanak menggunakan gambar untuk mengekspresikan, mengartikulasikan emosi, dan mencapai tingkatan berpikir tingkat tinggi (Brooks, 2009; Lomax, 2012; Matthews \& Jahanian, 1999), sebagai sarana komunikasi dan sarana presentasi yang berupa ide-ide nyata dan imajiner yang dapat menunjukkan perkembangan pemikiran anak-anak (Soundy, 2012), 
sedangkan mewarnai menjadi sarana untuk mengungkapkan imajinasi yang dimiliki, membantu mengenal perbedaan warna, melatih motorik halus dalam meningkatkan koordinasi tangan dan mata (Hijriyani \& Astuti, 2020), meningkatkan konsentrasi, dan melatih anak membuat target (Pratiwi et al., 2018; Utami, 2019). Hasil penelitian terdahulu juga mengungkapkan bahwa pembelajaran mewarnai gambar sebagai salah satu alternatif tindakan yang mengarah pada aktivitas menyenangkan anak dan mempengaruhi kreativitas anak (Aisyah, 2017; Shofiyah, 2013).

Berikutnya, dapat disimak bahwa pemanfaatan gadget dengan rata-rata paling rendah digunakan anak untuk bermain/game edukasi. Seperti pada hasil penelitian ini, orang tua mengambil perannya untuk memanfaatkan teknologi dalam hal games edukasi. Game edukasi merupakan permainan yang dikemas untuk menstimulasi kognitif dan meningkatkan konsentrasi anak. Selaras dengan pendapat Syofia (2018) bahwa bermain game dapat menstimulus kemampuan berpikir anak, misalnya game mengurutkan balok berdasarkan warna. Melalui game, penggabungan dari manfaat prinsip game dengan teknologi dapat menghasilkan sebuah konten edukasi sehingga anak termotivasi untuk belajar dengan konsep baru dalam konteks yang menghibur dan menyenangkan (Alia \& Irwansyah, 2018; Rozalia, 2017;Zemliansky \& Wilcox, 2010). Penelitian yang dilakukan Irsa et al. (2015) bahwa pembelajaran game edukasi calistung dapat meningkatkan minat belajar anak usia 3-8 tahun dengan presentase 78,33\% (sangat bagus). Setyawan dan Susanto (2017) juga menyatakan bahwa penggunaan media game berbasis android dapat meningkatkan kemampuan berbahasa terlihat dari indikator peningkatan kemampuan berbahasa siswa dari siklus I (53\%) dan siklus II (83\%). Hasil penelitian tersebut bertolak belakang dengan penelitian ini, dikarenakan ada beberapa faktor yang berpengaruh cukup besar misalnya peran orang tua serta tenaga pengajar atau guru dan sebaliknya dalam memberikan dukungan dan pemanfaatan teknologi. Hal ini selaras dengan pendapat Shaula dan Hasyim (2017) bahwa pembelajaran tidak akan efisien apabila tanpa dukungan dan peran orang tua serta pengajar atau guru dan sebaliknya dalam pembelajaran bertata krama. Munawar et al. (2019) juga menganjurkan adanya kesepakatan antara sekolah dan orang tua untuk controlling program berinternet sehat bagi anak. Melalui pemanfaatan teknologi yang ada, sekolah dapat menciptakan sebuah game yang tidak hanya mengajak anak-anak untuk sekedar bermain tanpa mendapatkan ilmu, namun sekolah dapat menciptakan sebuah permainan yang secara tidak langsung dapat memberikan ilmu pengetahuan bagi anak. Sehingga, game edukasi tidak akan digunakan untuk hiburan saja namun juga memberi nilai edukasi dan tujuan dari edukasinya tersampaikan.

Selain mengukur persentase pemanfaatan teknologi digital, penelitian ini juga menghitung persentase dari segi peran orang tua. Hasil survey terkait penilaian peran orang tua di era digital disajikan pada Tabel 2.

Tabel 2. Rata-rata Hasil Survey Peran Orang Tua

\begin{tabular}{clc}
\hline No & \multicolumn{1}{c}{ Peran Orang Tua } & Skor \\
\hline 1 & Melatih anak berpikir kritis terhadap gambar dan kata-kata & 3,477 \\
2 & Menjelaskan website yang boleh diakses oleh anak usia dini & 3,942 \\
3 & Melatih anak berkomunikasi dengan games dan film online & 2,884 \\
4 & Mendampingi anak untuk berkolaborasi upload foto dan video & 3,347 \\
5 & Melatih anak kreativitas upload foto dan video & 2,549 \\
\hline
\end{tabular}

Berdasarkan pada Tabel 2, maka dapat diketahui bahwa rata-rata tertinggi (peran yang sangat sering diperankan orang tua) terdapat pada penjelasan website yang boleh diakses oleh anak usia dini, sedangkan peran yang tidak pernah dilakukan (dengan rata-rata terendah) terdapat pada peran untuk melatih kreativitas anak dalam upload foto dan video. Hasil tersebut memberikan makna bahwa orang tua telah menjalankan perannya sebagai 
pendamping anak dalam pemanfaatan teknologi digital. Hal ini didukung oleh pendapat Purbasari \& Suryanto (2020) bahwa orang tua berperan dalam mendampingi anak digital native. Banyak sekali peran yang harus dimainkan oleh orang tua, terlebih saat ini telah memasuki era yang serba digital. Orang tua harus mampu mengarahkan anak dalam pemanfaatan teknologi secara bijak. Hal ini sejalan dengan pendapat Yulianingsih et al. (2021) bahwa untuk memanfaatkan media digital secara positif, maka anak-anak membutuhkan pendampingan orang tua.

Peran orang tua sangat dibutuhkan dalam proses perkembangan dan pertumbuhan anak termasuk dalam mengontrol dalam penggunaan gadget. Selaras dengan pendapat Lilawati (2021) bahwa orang tua memiliki tanggung jawab utama dalam proses pertumbuhan dan perkembangan anak. Davidson (2011) menunjukkan bahwa untuk bisa menggunakan internet dengan poitif, anak-anak membutuhkan bimbingan orang tua. Orang tua bertugas mengawasi, membatasi pemakaian serta mengarahkan anak menjadi lebih berprestasi dengan kemajuan teknologi yang ada untuk membangun anak Indonesia lebih maju dan berwawasan luas (Farida et al., 2021). Orang tua yang peduli terhadap anak berarti orang tua yang terlibat dalam seluruh dimensi pembentukan seseorang. Orang tua perlu menjelaskan website yang boleh diakses oleh anak usia dini. Orang tua harus sigap mengarahkan anak mereka untuk tidak membuka konten-konten yang menyimpang. Sejalan dengan pendapat Kiftiyah et al. (2017) bahwa salah satu peran orang tua dalam mendampingi penggunaan gawai pada anak prasekolah adalah dengan cara menstimulasi perkembangan kognitif anak melalui video youtube. Keterlibatan orang tua tidak hanya piawai dan paham segala macam hal dan istilah teknis dari perangkat dan media digital yang akan dibeli atau digunakan anak justru orang tua harus menempatkan fasilitas tersebut dengan benar dan dibawah pengawasan dan bimbingan yang baik. Hal sejalan dengan pendapat (Nurlina, 2019) bahwa upaya yang dapat dilakukan orang tua dalam mengawasi penggunaan gadget pada anak, seperti menemani dan membimbing dalam penggunaan gadget, membatasi penggunaan gadget, mengontrol isu atau data-data di dalam gadget anak.

Orang tua juga harus melatih anak berpikir kritis terhadap gambar dan kata-kata. Orang tua wajib meng-upgrade diri dengan informasi global terkini mengenai dunia dan tren anak zaman sekarang. Hal ini berarti mengharuskan orang tua untuk lebih maju satu tingkat di atas atau setidaknya setara dengan pengetahuan anak, sehingga orang tua dapat mengontrol perilaku dan aktivitas anak. Hasil penelitian Yulianingsih et al. (2021) mengungkap bahwa peran orang tua yang muncul secara umum selama pandemi COVID-19 yakni sebagai pembimbing, pendidik, penjaga, pengembang, dan pengawas. Orang tua perlu memberikan rambu-rambu untuk tidak mudah terpancing dengan konten-konten yang aneh dan tidak bermanfaat. Menurut Edy (2015), orang tua dapat melibatkan anak dalam berpikir kritis dengan memancing anak pada cerita atau kasus yang membahas tentang dampak negatif yang akan diterima anak jika tidak berhati-hati dalam penggunaan gadget apalagi yang sudah berakseskan internet. Orang tua adalah penentu masa depan dan keberhasilan anak yang dapat diwujudkan melalui bimbingan kelangsungan anak belajar di rumah (Umar, 2015).

Secara garis besar, penelitian ini telah memperlihatkan beberapa hal mengenai pemanfaatan teknologi digital terhadap peran orang tua. Pemanfaatan tersebut membutuhkan peran khusus orang tua agar tetap berjalan seimbang. Dari hasil pembahasan di atas, dapat dikatakan bahwa teknologi telah dimanfaatkan pada kegiatan yang positif. Sebelum dilakukan pengujian hipotesis, dilakukan uji kualitas data dengan uji reliabilitas dan validitas. Pengujian kualitas data dilakukan dengan menyusun inner model terlebih dahulu dan kemudian dilakukan analisis algoritma. Selanjutnya, dari hasil uji kualitas data adanya indikator kuisioner yang tidak valid tetapi sudah reliable, karena nilai validitas deskrminan yang didapat dari nilai average variance extracted (AVE) kurang dari 0,5 dan untuk nilai realibity sudah diatas 0,7. Hal ini sesuai dengan pernyataan Hartono \& Abdillah (2009) menyatakan bahwa data dikatakan reiabel apabila nilai cronbach alpha lebih dari 0,5 
dan data valid apabila nilai deskriminan validitasnya lebih dari 0,7. Gambar inner model dari indikator-indikator yang didrop sehingga dapat disajikan pada Gambar 2.

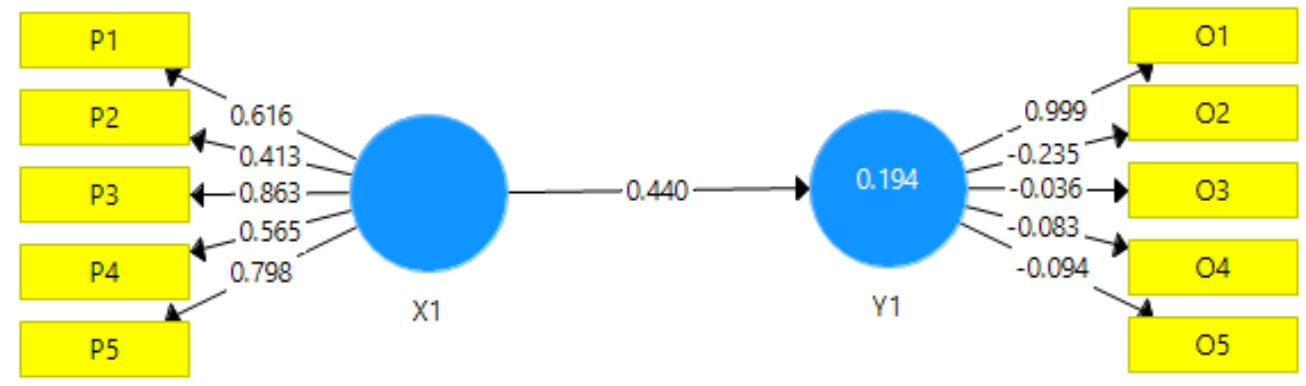

Gambar 2. Inner model modifikasi

Hasil uji kualitas data disajikan pada Tabel 3 dan hasil uji hipotesis untuk outer model dengan bootsrapping disajikan pada gambar 2 .

Tabel 3. Hasil Uji Kualitas Data

\begin{tabular}{lc}
\hline \multicolumn{1}{c}{ Variabel dan Indikator } & Outer Loading \\
\hline 1. Pemanfaatan untuk game edukasi (P1) & 0.616 \\
2. Pemanfaatan untuk mengaji (P2) & 0.413 \\
3. Pemanfaatan untuk mewarnai (P3) & 0.863 \\
4. Pemanfaatan untuk menggambar (P4) & 0.565 \\
5. Pemanfaatan untuk berhitung (P5) & 0.798 \\
6. Orang tua melatih anak untuk berpikir kritis terhadap gambar dan kata-kata (O1) & $\mathbf{0 . 9 9 9}$ \\
7. Orang tua menjelaskan website yang boleh diakses anak usia dini (O2) & -0.235 \\
8. Orang tua melatih anak berkomunikasi dengan games, film online (O3) & -0.036 \\
9. Orang tua mendampingi anak untuk berkolaborasi upload foto dan video (O4) & -0.083 \\
10. Orang tua melatih anak kreativitas upload foto dan video (O5) & -0.094 \\
\hline
\end{tabular}

Hasil uji kualifikasi data pada Tabel 3 menunjukkan bahwa nilai outer loading (untuk indikator refleksif) menunjukkan bobot dari setiap indikator sebagai pengukur dari masing-masing variabel laten. Indikator dengan outer weight/outer loading terbesar menunjukkan bahwa indikator tersebut sebagai pengukur variabel yang terkuat (dominan). Tabel 3 di atas menunjukkan bahwa variabel laten memiliki nilai loading di bawah 0.5 dengan demikian dapat disimpulkan bahwa pengukuran ini belum memenuhi persyaratan validitas konvergen.

Tabel 4. Hasil Uji Hipotesis

\begin{tabular}{ccccccc}
\hline $\begin{array}{c}\text { Simbol } \\
\text { Hipotesis }\end{array}$ & $\begin{array}{c}\text { Original } \\
\text { Sample }\end{array}$ & $\begin{array}{c}\text { Sample } \\
\text { Mean }\end{array}$ & $\begin{array}{c}\text { Standard } \\
\text { Deviation }\end{array}$ & $\begin{array}{c}\mathrm{T} \\
\text { Statistics }\end{array}$ & $\begin{array}{c}\mathrm{P} \\
\text { Values }\end{array}$ & Simpulan \\
\hline $\mathrm{X} 1->\mathrm{Y} 1$ & 0.440 & 0.412 & 0.145 & 3.041 & 0.002 & Diterima \\
\hline
\end{tabular}

Uji signifikansi pada model SEM dengan PLS bertujuan untuk mengetahui pengaruh variabel eksogen terhadap variabel endogen. Pengujian hipotesis dengan metode SEM PLS dilakukan dengan cara melakukan proses bootstrapping dengan bantuan program komputer smartPLS 3.0 sehingga diperoleh hubungan atara variabel pemanfaatan gadget pada anak usia dini terhadap peran oran tua. Sebelum dilakukan pengujian hipotesis, diketahui bahwa nilai T-tabel untuk tingkat kepercayaan sebesar 95\% (a sebesar 5\%) dan derajat kebebasan $(\mathrm{df})=\mathrm{n}-2=277-2=275$ adalah sebesar 1,97 .

Berdasarkan hasil output Tabel 4. Statistik untuk variabel pengaruh pemanfaatan gadget (X1) terhadap peran orang tua (Y1) sebesar $3.041>$ T-tabel (1.97). Nilai original sample estimate menunjukkan nilai positif sebesar 0.440 yang menunjukkan bahwa arah hubungan 
variabel pemanfaatan gadget (X1) terhadap variabel peran orang tua (Y1) adalah positif. Dengan demikian, keputusan hipotesis pada penelitian diterima. Artinya, dalam penelitian ini variabel laten pemanfaatan gadget (X1) berpengaruh terhadap variabel laten peran orang tua (Y1) secara signifikan.

Hasil Penelitian ini relevan dengan beberapa penelitian bahwa waktu penggunaan layar pada anak merupakan hasil interaksi antara faktor anak dan sikap orang tua (Blackwell et al., 2014; Genc, 2014; McCloskey et al., 2018; Vittrup et al., 2016). Peran orang tua dalam melaksanakan pendampingan terhadap anak-anak dalam menggunakan teknologi digital merupakan bentuk tanggung jawab utama karena keluarga merupakan tempat pendidikan pertama. Senada dengan pendapat Lestari (2016) menjelaskan bahwa komunikasi antara orang tua dan anak, dalam hal ini hubungan antara ayah dan anak memang memegang peranan penting bagi orang tua untuk melakukan kontrol, pemantauan, dan dukungan pada anak, sedangkan keterlibatan ibu lebih kepada kesadaran mengenai pendidikan anak. Penelitian yang dilakukan Supriyono (2020) juga menunjukkan bahwa orang tua sangat berperan penting dalam menyikapi penggunaan gadget dengan mendampingi anak ketika bermain gadget. Hasil penelitian ini juga sesuai dengan Pradevi (2020) bahwa terdapat hubungan positif signifikan antara pengawasan orang tua dalam penggunaan gadget dengan kemampuan berempati anak sebesar 0.941>0.05.

Adanya pengaruh antara pemanfaatan gadget terhadap peran orang tua sangat penting dipahami orang tua dalam mendidik anak di era digital. Hasil penelitian ini dapat dijadikan referensi oleh orang tua dalam mengawasi dan membatasi penggunaan gadget bagi anak usia dini. Orang tua harus lebih berkompeten dan tahu lebih mendalam tentang penggunaan aplikasi yang akan digunakan anak, sehingga orang tua tetap bisa mengontrol aktivitas anaknya ketika menggunakan gadget. Kebaruan dalam penelitian ini secara lebih spesifik lebih terfokus pada pemanfaatan gadget pada anak usia dini dengan memanfaatkan aplikasi-aplikasi yang sudah disedikan dari sekolah ataupun pemerintah.

Adapun keterbatasan dalam penelitian ini adalah situasi pandemic covid-19 mengharuskan peneliti menjaga jarak selama mengumpulkan data hasil angket dilakukan secara daring. Selain itu, keterbatasan lain penelitian ini hanya menganalisis dari segi penggunaan gadget tanpa mengaitkan dengan variabel laten lain, seperti sikap tata krama, emosi, kemampuan empatik anak, penyimpangan perilaku seksual, dll. Saran untuk peneliti selanjutnya, sebaiknya melakukan penelitian yang lebih mendalam pada peran digital native education terhadap upaya membekali orang tua, sehingga orang tua mampu mempersiapkan anak dalam menghadapi pesatnya perkembangan teknologi. Selain itu, penelitian dapat dikaitkan dengan faktor-faktor lain atau pun karakteristik responden maupun subjek yang dapat mempengaruhi hubungan gadget dengan kemampuan anak lainnya.

\section{SIMPULAN}

Penelitian menunjukkan pengaruh yang positif pemanfaatan gadget pada anak usia dini terhadap peran orang tua. Pemanfaatan gadget berupa mengaji, mewarnai, menggambar, mengenal huruf; angka; membaca; dan berhitung, serta games edukasi. Oleh karena itu, orang tua berperan penting sebagai pembimbing, pendidik, dan pengawas dalam menyikapi penggunaan gadget oleh anak. Hal ini dilakukan agar anak tidak menyalagunakan untuk kegiatan lain. Sikap yang perlu ditunjukkan yaitu mendampingi anak ketika bermain gadget dan orang tua harus bisa mengoperasikannya. Hasil penelitian ini dapat dijadikan petunjuk bagi orang tua dalam memanfaatkan teknologi sehingga orang tua dapat memaksimalkan perannya dengan segala perkembangan yang terjadi.

\section{UCAPAN TERIMA KASIH}

Penulis ucapkan terima kasih kepada seluruh responden (orang tua) PAUD di Provinsi Banten, Jawa Barat sehingga pelaksanaan penelitian ini berjalan dengan lancar. 


\section{DAFTAR PUSTAKA}

Ahsani, E. L. F. (2020). Strategi Orang Tua dalam Mengajar dan Mendidik Anak dalam Pembelajaran At The Home Masa Pandemi Covid-19. Jurnal Al_Athfal, 3(1), 37-46.

Aisyah. (2017). Permainan Warna Berpengaruh Terhadap Kreativitas Anak Usia Dini. Jurnal Obsesi: Jurnal Pendidikan Anak Usia Dini, 1(2), 118-123. https://doi.org/10.31004/obsesi.v1i2.23

Aisyatinnaba, N., \& Sutoyo, A. (2016). Peran Orang Tua Dalam Memotivasi Belajar Siswa. Indonesian Journal of Guidance and Counseling, 5(3), 52-57. https://doi.org/10.15294/ijgc.v5i4.13520

Alia, T., \& Irwansyah. (2018). Pendampingan Orang Tua pada Anak Usia Dini dalam Penggunaan Teknologi Digital. A Journal of Language, Literature, Culture, and Education, 14(1), 65-78. https:/ / doi.org/http://dx.doi.org/10.19166/ pji.v14i1.639

Arifin, Z. (2019). Pemanfaatan Media Game Monopoli Ayo Mengaji Dalam Meningkatkan Gemar Mengaji Al-Qur`an. Jurnal Penelitian, 13(2), 197-214.

Azwar, S. (2016). Konstruksi tes kemampuan kognitif. Yogyakarta: Pustaka Pelajar.

Barovih, G., Sugara, E. P. A., \& Nurussama. (2020). Pemanfaatan Aplikasi Sebagai Media Bantu Edukasi Agama Islam Untuk Anak Usia Dini. Dinamisia: Jurnal Pengabdian Kepada Masyarakat, 4(1), 150-158. https:// doi.org/10.31849/dinamisia.v4i1.3339

Blackwell, C. K., Lauricella, A. R., \& Wartella, E. (2014). Factors influencing digital technology use in early childhood education. Computers and Education, 77, 82-90. https:// doi.org/10.1016/j.compedu.2014.04.013

Brooks, M. (2009). Drawing, visualisation and young children's exploration of "big ideas." International Journal of Science Education, 31(3), 319-341. https://doi.org/10.1080/09500690802595771

Chusna, P. A., \& Utami, A. D. M. (2020). Dampak Pandemi Covid-19 Terhadap Peran Orang Tua Dan Guru Dalam Meningkatkan Kualitas Pembelajaran Daring Anak Usia Sekolah Dasar. PREMIERE: Journal of Islamic Elementary Education, 2(1), 11-30. https://doi.org/10.51675/jp.v2i1.84

Creswell, J. W., \& Creswell, J. D. (2017). Research design: Qualitative, quantitative, and mixed methods approaches. Sage Publications.

Davidson, C. (2011). Seeking The Green Basilisk Lizard: Acquiring Digital Literacy Practices in The Home. Journal of Early Childhood Literacy, 12(1), 24-45. https:// doi.org/10.1177/1468798411416788

Ebi, S. (2017). Golden Age Parenting: Memaksimalkan Potensi Anak di Usia Emas. Psikologi Center.

Edy, A. (2015). Ayah Edy menjawab problematika orangtua ABG dan remaja. Jakarta: Noura Book Publising.

Elihami, E., \& Ekawati, E. (2020). Persepsi Revolusi Mental Orang Tua terhadap Pendidikan Anak Usia Dini. Jurnal Edukasi Nonformal, 1(2), 16-31.

Farida, Hanafiah, S. U., Hayati, L. L. N., Ramadhani, J., \& Saputri, Y. (2021). Optimasi Gadget dan Implikasinya terhadap Pola Asuh Anak. Journal Inovasi Penelitian, 1(8), 1701-1710. https://doi.org/https://doi.org/10.47492/jip.v1i8.316

Farkhatin, N. (2018). Implementasi Software Berhitung Berbasis Android di Taman Kanakkanak Kecamatan Jagakarsa. STRING (Satuan Tulisan Riset Dan Inovasi Teknologi), 2(3), 249. https:// doi.org/10.30998/string.v2i3.2432

Ferliana, J. M. (2013). Asesmen Dalam Pendidikan Anak Usia Dini. Universitas Krida Wacana.

Fithri, D. L., \& Setiawan, D. A. (2017). Analisa Dan Perancangan Game Edukasi Sebagai Motivasi Belajar Untuk Anak Usia Dini. Simetris: Jurnal Teknik Mesin, Elektro Dan Ilmu Komputer, 8(1), 225-230. https://doi.org/10.24176/ simet.v8i1.959

Fujiawati, F. S., Raharja, R. M., \& Iman, A. (2020). Pemanfaatan Teknologi untuk Pendiidkan Anak Usia Dini di Masa Pandemi Covid-19. Prosiding Seminar Nasional Pendidikan FKIP, 3(1), 120-125. 
Genc, Z. (2014). Parents' Perceptions about the Mobile Technology Use of Preschool Aged Children. Procedia - Social and Behavioral Sciences, 146, 55-60. https:// doi.org/10.1016/j.sbspro.2014.08.086

Gunawan, W. (2019). Pengembangan Aplikasi Berbasis Android Untuk Pengenalan Huruf Hijaiyah. Jurnal Informatika, 6(1), 69-76. https:// doi.org/10.31311/ji.v6i1.5373

Hardiyana, A. (2016). Optimalisasi Pemanfaatan Teknologi Informasi dan Komunikasi Dalam Pembelajaran Paud. AWLADY: Jurnal Pendidikan Anak, 2(1), 1-12. https:/ / doi.org/10.24235/awlady.v2i1.762

Hartono, J., \& Abdillah, W. (2009). Konsep dan Aplikasi PLS (Partial Least Square) Untuk Penelitian Empiris. BPFE.

Haryanto, \& Friana, B. (2018). Aplikasi Permainan Edukatif Mengaji Berbasis Multimedia Interaktif. Jurnal Teknik Informatika UNIS, 6(1), 8-16. https:// doi.org/https:// doi.org/10.33592/jutis.Vol6.Iss1.36

Hijriyani, Y. S., \& Astuti, R. (2020). Penggunaan Gadget Oleh Anak Usia Dini Pada Era Revolusi Industri 4.0. Jurnal Inovasi Pendidikan Guru Raudhatul Athfal, 8(1), 16-28. https:/ / doi.org/10.21043/thufula.v8i1.6636

Hoerunnisa, A., Suryani, N., \& Efendi, A. (2019). The Effectiveness of the Use of E-Learning in Multimedia Classes to Improve Vocational Students' Learning Achievement and Motivation. Jurnal Teknologi Pendidikan, 07(02), 123-137. https:// doi.org/10.31800/jtp.kw.v7n2.p123--137

Iftitah, S. L., \& Anawaty, M. F. (2020). Peran Orang Tua Dalam Mendampingi Anak di Rumah Selama Pandemi Covid-19. JCE (Journal of Childhood Education), 4(2), 71. https:// doi.org/10.30736/jce.v4i2.256

Irhandayaningsih, A. (2019). Menanamkan Budaya Membaca pada Anak Usia Dini. Anuva: Jurnal Kajian Budaya, $3(2), \quad 109-118$. https:// doi.org/https:// doi.org/10.14710/anuva.3.2.109-118

Irma, C. N., Nisa, K., \& Sururiyah, S. K. (2019). Keterlibatan Orang Tua dalam Pendidikan Anak Usia Dini di TK Masyithoh 1 Purworejo. Jurnal Obsesi : Jurnal Pendidikan Anak Usia Dini, 3(1), 214. https:// doi.org/10.31004/obsesi.v3i1.152

Irsa, D., Wiryasaputra, R., \& Primaini, S. (2015). Perancangan Aplikasi Game Edukasi Pembelajaran Anak Usia Dini Menggunakan Linear Congruent Method ( LCM ) Berbasis Android. Jurnal Informatika Global, 6(1), 7-14. https:// doi.org/http://dx.doi.org/10.36982/jiig.v6i1.4

Kiftiyah, I. N., Sagita, S., \& Ashar, A. B. (2017). Peran Media Youtube Sebagai Sarana Optimalisasi Perkembangan Kognitif Pada Anak Usia Dini. Prosiding SEMNAS Penguatan Individu Di Era Revolusi Informasi, 1998, 199-208.

Kurniati, E., Alfaeni, D. K. N., \& Andriani, F. (2021). Analisis Peran Orang Tua dalam Mendampingi Anak di Masa Pandemi Covid-19. Jurnal Obsesi : Jurnal Pendidikan Anak Usia Dini, 5(1), 241-256. https://doi.org/10.31004/obsesi.v5i1.541

Lestari, S. (2016). Psikologi Keluarga: Penanaman Nilai dan Penanaman Konflik dalam Keluarga. Prenada Media.

Lilawati, A. (2021). Peran Orang Tua dalam Mendukung Kegiatan Pembelajaran di Rumah pada Masa Pandemi. Jurnal Obsesi : Jurnal Pendidikan Anak Usia Dini, 5(1), 549-558. https:// doi.org/10.31004/obsesi.v5i1.630

Lomax, H. (2012). Contested voices? Methodological tensions in creative visual research with children. International Journal of Social Research Methodology, 15(2), 105-117. https:// doi.org/10.1080/13645579.2012.649408

Luciana, C. V. (2015). Hubungan Peranan Otang Tua terhadap Minat Belajar Anak Usia Dini. Bunga Rampai Usia Emas, 1(1), 37-44.

Matthews, J. M., \& Jahanian, S. (1999). A Pedagogical Strategy for Gradual Enhancement of Creative Performance of the Students. European Journal of Engineering Education, 24(1), 49-58. https:// doi.org/10.1080/03043799908923537 
DOI: $10.31004 /$ obsesi.v6i1.1170

McCloskey, M., Johnson, S. L., Benz, C., Thompson, D. A., Chamberlin, B., Clark, L., \& Bellows, L. L. (2018). Parent Perceptions of Mobile Device Use Among PreschoolAged Children in Rural Head Start Centers. Journal of Nutrition Education and Behavior, 50(1), 83-89.e1. https:// doi.org/10.1016/j.jneb.2017.03.006

Munawar, M., Fakhruddin, RC, A. R., \& Prihatin, T. (2019). Keterlibatan Orangtua dalam Pendidikan Literasi Digital Ank Usia Dini. Seminar Nasional Pascasarjana 2019, 1-5.

Nisa, K. F., Khoiri, N., \& Wijayanto. (2020). Aplikasi Pengenalan Huruf Hijaiyyah Berbasis Android Menggunakan Unity 3D. Jurnal Ilmiah Penelitian Teknologi Informasi $\mathcal{E}$ Komputer, 1(1), 21-27.

Novianti, R., \& Garzia, M. (2020). Penggunaan Gadget pada Anak; Tantangan Baru Orang Tua Milenial. Jurnal Obsesi: Jurnal Pendidikan Anak Usia Dini, 4(2), 1000. https://doi.org/10.31004/obsesi.v4i2.490

Nurlina. (2019). Peran Orang Tua dalam Pembentukan Kepribadian Anak di Era Digital. An Nisa ' Jurnal Studi Gender Dan Anak, 12(1), 549-559.

Pradevi, A. P. (2020). Hubungan Pengawasan Orang Tua dalam Penggunaan Gadget dengan Kemampuan Empati Anak. Jurnal Pendidikan Anak, 9(1), 49-56. https://doi.org/10.21831/jpa.v9i1.31402

Pratiwi, M. R., Mukaromah, \& Herdiningsih, W. (2018). Peran Pengawasan Orangtua Pada Anak Pengguna Media Sosial. Jurnal Penelitian Pers Dan Komunikasi Pembangunan, 22(1), 35-57. https://doi.org/https://doi.org/10.46426/jp2kp.v22i1.73

Purbasari, Y. A., \& Suryanto, S. (2020). Peran Orang Tua Dalam Pendampingan Anak Digital Native. Prosiding Seminar Nasional 2020 Fakultas Psikologi UMBY, 38-48.

Raghubar, K. P., \& Barnes, M. A. (2016). Early Numeracy Skills In Preschool-Aged Children: A Review of Neurocognitive Findings and Implications for Assessment and Intervention. Clinical Neuropsychologist, 31(2), 329-351. https:// doi.org/10.1080/13854046.2016.1259387

Reswita, R., \& Wahyuni, S. (2018). Efektivitas Media Pasir dalam Meningkatkan Kemampuan Konsep Bilangan pada Anak Usia 5-6 Tahun di Tk Aisyiyah Bengkalis. Lectura : Jurnal Pendidikan, 9(1), 43-51. https://doi.org/10.31849/lectura.v9i1.927

Rozalia, M. F. (2017). Hubungan Intensitas Pemanfaatan Gadget dengan Prestasi Belajar Siswa Kelas V Sekolah Dasar. Jurnal Pemikiran Dan Pengembangan SD, 5(2), 722-731. https://doi.org/https://doi.org/10.22219/jp2sd.v5i2.4821

Sahriana, N. (2019). Pentingnya Peran Orang Tua dalam Penggunaan Gadget pada Anak Usia Dini. JURNAL Smart PAUD, 2(1), 60-66. https://doi.org/http://dx.doi.org/10.36709/jspaud.v2i1.5922

Santosa, E. T. (2015). Raising Children In Digital Era. Elex Media Komputindo.

Setyawan, F. H., \& Susanto, S. (2017). Penggunaan Media Game Edukasi Berbasis Android untuk Meningkatkan Kemampuan Berbahasa Anak Usia Dini. Jurnal Pendidikan Modern, 3(1), 28-35. https://doi.org/https://doi.org/10.37471/jpm.v3i1.45

Shaula, D. F., \& Hasyim, N. (2017). Menanamkan Konsep Tata Krama pada Anak melalui Perancangan Game Edukasi. Jurnal Informatika Upgris, 3(1), 38-44. https://doi.org/10.26877/jiu.v3i1.1609

Shofiyah. (2013). Penerapan Pembelajaran Mewarnai Gambar dalam Meningkatkan Motorik Halus Anak Kelompok B di TK Hidayatus Shibyan. Jurnal IT-EDU, 2(2), 1-8.

Soundy, C. S. (2012). Searching for Deeper Meaning in Children's Drawings. Childhood Education, 88(1), 45-51. https:// doi.org/10.1080/00094056.2012.643718

Supriyono, L. (2020). Peran Orang Tua dalam Menyikapi Gadget dan Implikasinya terhadap Penyimpangan Perilaku Seksual Anak. PROFETIKA Jurnal Studi Islam, 21(2), 159-166.

Syofia, S. V. (2018). Hubungan Penggunaan Gadget dengan Perkembangan Anak Usia Prasekolah di PAUD/ TK Islam Budi Mulia. Menara Ilmu Journal, 12(2), 137-145. https://doi.org/https://doi.org/10.33559/mi.v12i80.634

Ulfa, S. (2016). Pemanfaatan Teknologi Bergerak Sebagai Media Pembelajaran bagi Anak 
Usia Dini. Edcomtech Jurnal Kajian Teknologi Pendidikan, 1(1), 1-8.

Umar, M. (2015). Peranan Orang Tua dalam Peningkatan Prestasi Belajar Anak. JURNAL EDUKASI: Jurnal Bimbingan Konseling, 1(1), 20. https:/ / doi.org/10.22373/je.v1i1.315

Utami, F. (2019). Pengaruh Penggunaan Aplikasi Bubybus pada Gadget Terhadap Kemampuan Literasi Awal pada Anak Kelompok A di PAUD IT Fathiyyah. Prosiding Seminar Nasional Pendidikan Program Pascasarjana Universitas PGRI Palembang, 299-307.

Vittrup, B., Snider, S., Rose, K. K., \& Rippy, J. (2016). Parental Perceptions of The Role of Media and Technology in their Young Children's Lives. Journal of Early Childhood Research, 14(1), 43-54. https:// doi.org/10.1177/1476718X14523749

Warisyah, Y. (2015). Pentingnya "pendampingan dialogis" orang tua dalam penggunaan gadget pada anak usia dini. Seminar Nasional Pendidikan 2015, 130-138.

Yulianingsih, W., Suhandji, Nugroho, R., \& Mustakim. (2021). Keterlibatan Orangtua dalam Pendampingan Belajar Anak selama Masa Pandemi Covid-19. Jurnal Obsesi: Jurnal Pendidikan Anak Usia Dini, 5(2), 1138-1150. https:/ / doi.org/10.31004/obsesi.v5i2.740

Zaini, M., \& Soenarto. (2019). Persepsi Orangtua terhadap Hadirnya Era Teknologi Digital di Kalangan Anak Usia Dini. Jurnal Obsesi: Jurnal Pendidikan Anak Usia Dini, 3(1), $254-$ 264. https://doi.org/10.31004/obsesi.v3i1.127

Zemliansky, P., \& Wilcox, D. (2010). Design and Implementation of Educational Games: Theoretical and Practical Perspectives: Theoretical and Practical Perspectives. IGI Global. 